\title{
Context, Intersubjectivism, and Value: Humean Constructivism Revisited
}

\author{
JOCELYN MACLURE Université Laval
}

ABSTRACT: I defend a version of what Sharon Street called "Humean constructivism." I'll first sketch out why I think that contextual constructivism provides us with a more plausible understanding of the ontological status of values than both Kantian constructivism and moral realism. In addition to its recognition of the role of evolutionary pressures in the emergence of human morality, contextual constructivism must now clarify the role of historical intersubjectivity in the subsequent development of morality. I will then claim that adding a coherentist module to Humean constructivism provides a satisfactory answer to those who fear that contextual metaethical theories can only be non-cognitivist. Finally, I will sketch out why I think that the notion of a mind-independent "space of moral reasons" is largely compatible with Humean constructivism.

RÉSUMÉ : Je défends dans ce texte une version particulière de la position que Sharon Street a appelée le «constructivisme humien». J'esquisserai pourquoi je considère que ce constructivisme est préférable à la fois au réalisme moral et au constructivisme kantien sur le plan de la compréhension du statut ontologique des valeurs. Après avoir accepté de reconnaître le rôle des pressions de l'évolution dans l'émergence de la moralité, le constructivisme humien doit toutefois préciser le rôle de l'intersubjectivité historique dans l'évolution subséquente de la morale. J'expliquerai aussi pourquoi je considère que l'intégration d'un volet cohérentiste au constructivisme permet d'atténuer les craintes concernant le caractère potentiellement non-cognitiviste des théories contextualistes. Enfin, j'esquisserai pourquoi l'idée d'un «espace des raisons morales» indépendant, à certains égards, de l'esprit humain est compatible avec le constructivisme humien.

Dialogue 59 (2020), 377-401

(C) Canadian Philosophical Association/Association canadienne de philosophie 2020 doi:10.1017/S0012217320000086 
Keywords: moral ontology, moral epistemology, Humean constructivism, coherentism, contextualism, historical intersubjectivity, moral realism

\section{Introduction}

In this paper, I defend a particular version of the position that Sharon Street called "Humean constructivism," which I interpret as a contextualist variant of metaethical constructivism. I will outline why I consider that contextualist constructivism is preferable to both moral realism and Kantian constructivism in terms of understanding the ontological status of moral values. I will argue that, after acknowledging the role of evolutionary pressures in the emergence of human morality, Humean constructivism must now specify the role of historical intersubjectivity in the subsequent evolution of morality. I understand 'historical intersubjectivity' as referring to the intentional practices responsible for the actualization and sedimentation of moral values in particular historical contexts, with a particular emphasis on the expression of moral disagreement and on the justice claims made by individual or collective agents. This is a version of the view that Kate Manne calls 'intersubjectivism." ${ }^{2}$ Some metaethicists will think that I am thereby dissolving metaethics in normative ethics, as others did for different reasons. ${ }^{3}$ This is not the case. The amendment I will propose to Humean constructivism does not offer any answers to the first-order substantial ethical questions that we face. It does not allow us to solve our moral enigmas or arbitrate the moral disagreements that are the hallmark of democratic societies. The further development of the contextualist dimension of Humean constructivism can at best improve our understanding of the ontological constitution of human morality. It is the addition of a coherentist module to Humean constructivism that provides a theory of moral justification and allows the elaboration of fallible but reasoned answers to our moral perplexities.

After reflecting on the relationship between moral ontology and moral epistemology, I will contrast Kantian and Humean constructivisms. In the section, 'Morality and Evolution,' I will briefly recall why many now consider that pressures stemming from the biological evolution of humans have favoured the emergence of moral norms, and why this linkage between morality and evolution poses a serious challenge to moral realism. I will then suggest that, after having recognized the role of evolutionary pressures, Humean constructivism must now clarify the role of historical intersubjectivity and of social practices in the constitution of morality. In Section 8, I will indicate why the notion which is often claimed by moral realists — of a 'space of moral reasons' that is independent, in some respects, with regard to the human mind, is compatible with Humean constructivism. 


\section{Moral Ontology and Moral Epistemology}

For the purpose of this paper, I rely on a fairly firm distinction between two subfields of metaethics, namely moral ontology and moral epistemology. Moral ontology is concerned with the nature of morality and its mode of existence. 'Existence' is understood here as what emerges or appears in a particular field or realm of reality. ${ }^{4}$ Moral epistemology, however, deals with our access to the normative realm of values and with the epistemic status of moral utterances, asking among other things whether they are truth-apt, or, in a deflationary perspective, whether it is possible to assess their reasonableness and to compare and rank them. One of the implications of this distinction is that we must resist the idea, sometimes claimed by moral realists, that 'realism' and 'cognitivism' are synonymous. A cognitivist theory states that moral statements are propositional, i.e., that they have cognitive content and that they can be true or false. As such, realism and constructivism can be cognitivist. The boundary between moral ontology and moral epistemology is in many other respects porous - if moral facts exist in the same way that the facts revealed by the natural sciences do, this leads to the view that a correspondence theory of moral truth is needed - but a distinction between the two areas remains necessary to understand where the disagreement between realism and constructivism lies.

If this is right, the most philosophically substantial distinction between realism and constructivism concerns the ontological status of morality. For the purposes of my argument, the most decisive disagreement between the two positions concerns the relationship between morality and the human mind. The realist argues that there are mind-independent moral facts and, accordingly, that moral truths are independent of agents' attitudes and beliefs. Values or moral principles are part of a dimension of reality that is not constituted by mental states. ${ }^{5}$ Realism holds that there are moral facts, natural or not, that exist independently of the beliefs of the agents and which allow them to evaluate the validity of moral judgements. ${ }^{6}$ Constructivism denies this independence by arguing that there are no mind-independent moral facts and that the moral principles or judgements that are true or whose authority must be recognized, are produced, in one way or another, by human minds; that is, they result from the intentions, attitudes, deliberations, or practices of agents.

The thesis I defend is constructivist in the sense that I believe that moral principles are brought about by intentional human practices. If mind-independent facts do exist, as scientific realism holds - the existence of elementary particles,

4 Gabriel, Fields of Sense, p. 95.

5 Jacobs, Dimensions of Moral Theory, p. 9.

6 Miller, An Introduction to Contemporary Metaethics, Chapter 1; Ogien, “Qu'est-ce que le réalisme moral?" 
tectonic plates, and the stars of our galaxy does not depend on our attitudes and beliefs - values can be thought of as depending at least in part on our attitudes, beliefs, and actions. In the same way that we can think that mathematical structures, unlike atoms and genes, are deduced or imagined by the human mind to better understand a reality that does not already contain them, one can plausibly think that moral values are the result of the interaction between agents who have to solve coordination and cooperation problems. In a general metaphysical conception of reality, I see values as closer to the social institutional facts theorized, for instance, by John Searle ${ }^{7}$ than to the natural facts revealed by the natural sciences. Values, money, positive law, soccer tournaments, and happy hours exist but depend on the beliefs and practices of agents. Institutional facts, for Searle, are objective facts; however, their objectivity depends upon human agreement, on their implicit or explicit acceptance by the members of a community. ${ }^{8}$

The jury is still out about the theoretical status of constructivism and about whether it truly belongs to metaethics. ${ }^{9}$ Without going into the specifics, I consider that a constructivist position is a normative ethical theory if it claims that the correct application of a particular deliberative procedure leads to moral truth or allows us to assess the validity or reasonableness of moral judgements or principles. ${ }^{10}$ The Kantian categorical imperative, the Rawlsian original position, Thomas M. Scanlon's moral contractualism, and Jürgen Habermas' ethics of discussion are all constructivist positions within the field of normative ethical theory. ${ }^{11}$ These theories can be agnostic with regard to the ontological nature of morality or of normativity in general, ${ }^{12}$ or they can be combined with properly metaethical theories. If Habermas remains a constructivist at the metaethical level by founding moral truth on what he considers to be the normative presuppositions implicit in interlocution or in "communicative action," Scanlon defends a realist thesis about the existence of normative reasons in general. ${ }^{13}$

\footnotetext{
7 Searle, Making the Social World.

8 Searle, Making the Social World, p. 10.

9 Enoch, "Can There Be a Global, Interesting, Coherent Constructivism about Practical Reason?"; Bagnoli, "Constructivism in Metaethics"; Turmel and Rocheleau-Houle, "Le constructivisme est-il une métaéthique?"

10 Bagnoli, "Constructivism in Metaethics," Part 6.

11 Habermas, Moral Consciousness and Communicative Action; Kant, Fondements de la métaphysique des mours; Rawls, A Theory of Justice; Scanlon, What We Owe to Each Other.

12 Rawls, Political Liberalism.

13 Habermas, The Theory of Communicative Action; Scanlon, Being Realistic about Reasons. Unlike Street and Scanlon, I will focus in this paper on a subset of the agent's reasons for action, namely moral values.
} 


\section{Procedural Rationalism}

A constructivist believes that morality is at least partially dependent on mental activity and, in particular, on practical rationality. ${ }^{14}$ The dominant approach within the family of constructivist theories is procedural rationalism, most often derived from Kant's moral philosophy. Moral principles and judgements are seen as the result of the correct exercise of our rational faculties, especially those constituting practical reason. Contrary to realist positions, constructivism holds that we do not have access to substantial criteria that are independent of the reflexive procedures deployed by rational agents. As John Rawls put it, "[m]oral objectivity is to be understood in terms of a suitably constructed social point of view that all can accept. Apart from the procedure of constructing the principles of justice, there are no moral facts." 15

Many constructivists build upon one of the three formulations of the Kantian categorical imperative so as to propose a procedure, a maxim, or a thought experiment to establish what the moral obligations of agents are, or to justify particular moral judgements. ${ }^{16}$ The procedures or thought experiments generally serve to produce impartial moral judgements, as when I ask if I can want the maxim of my action to become a universal law or to be adopted by all. Rawls' original position is an example, as the epistemic constraint of the veil of ignorance prevents agents from choosing principles of justice that will favour them once the veil is lifted. Scanlon argues that an action is morally wrong or unjust if it is contradicted by a principle that no one can reasonably reject. ${ }^{17}$

What generally motivates constructivists to reject realism is the metaphysical discomfort regarding the status of moral facts, which would exist even if they were not perceived, or thought of, by any human mind - just like water and air molecules. Realists accept that morality evolves - if only from an empirical point of view - in relation to the desires, intentions, beliefs, and actions of human beings, but add that independent moral facts are nevertheless part in one way or another of the fabric of the world. Accordingly, realists can state, for instance, that the emergence of a robust norm of individual autonomy in modernity was not contingent. The Ancients, who had different standards to evaluate the relationship between the moral claims arising from individuals, traditions, and collective decisions, were simply misguided. Just as it took our

14 'Partially' because non-normative facts — such as the fact that human beings are sentient beings capable of suffering and of experiencing pleasure - are also required to explain morality.

15 Rawls, "Kantian Constructivism in Moral Theory," p. 519; see also Darwall, Gibbard, and Railton, "Toward Fin de siècle Ethics."

16 Habermas, Moral Consciousness and Communicative Action; O'Neill, Constructions of Reason.

17 Scanlon, "Contractualism and Utilitarianism." 
predecessors a long time to discover heliocentrism and the chemical structure of water, it took take them about the same amount of time to discover the truth or superiority of moral individualism.

That being said, those of us who persist in seeing these independent moral facts as metaphysically mysterious can also be sceptical about the Kantian constructivists' confidence in deliberative procedures arising from practical rationality. It is easy to accept that the procedures imagined by Kantians are powerful heuristics to reason about what we ought to do, about what we owe to each other, and about political norms and ends. But is it plausible to maintain that values owe their existence to a deliberative procedure? At best, it can be said that success in universalization tests can help us validate moral principles such as equality, freedom, or dignity, which have already emerged in particular historical contexts. In addition, and as has been noted many times since the Hegelian critique of the Kantian categorical imperative's empty formalism, procedural constructivism suffers from the problem of undue indeterminacy. When it comes to thinking about our actions or about the resolution of normative disagreements, the principle that my judgement must be able to be endorsed by others only displaces the problem to a higher level of abstraction. In more complex or controversial cases - think, for instance, about abortion - it is often possible for the holders of competing positions to argue that their reasons are universalizable, or that they should be accepted by any reasonable person.

\section{Humean Constructivism}

It is for these kinds of reasons that what Street called "Humean constructivism" has become a rallying point in recent years for those who have serious reservations about both moral realism and Kantian constructivism, but who are nevertheless not ready to accept a non-cognitivist thesis, or an error theory like J.L. Mackie's. In addition to having put forward serious criticisms of realism, ${ }^{18}$ Street has developed an alternative constructivist position, which posits that, when thinking about the existence of reasons for action, we must start from the point of view of the evaluating creatures that we already are, that is, from the fact that we are agents who already use normative concepts in our apprehension of the world. This is what she calls the "practical point of view":

[T] he practical point of view is the point of view occupied by any creature who takes at least some things in the world to be good or bad, better or worse, required or optional, worthy or worthless, and so on - the standpoint of a being who judges, whether at a reflective or unreflective level, that some things call for, demand, or provide reasons for others. ${ }^{19}$

18 Street, "A Darwinian Dilemma for Realist Theories of Value," and "Objectivity and Truth."

19 Street, "What is Constructivism in Ethics and Metaethics?" p. 366. 
She then offers a Humean rather than a Kantian formulation of the practical point of view. Her theory is Humean, among other things, because, unlike idealized conceptions of practical reason, she takes contingency and context seriously, in the sense that she starts from agents' contingent psychological make-up and from their beliefs and concrete axiological commitments at a given point in time. Street is not unduly tormented by the apparent unavailability of a transcendental or impersonal point of view. ${ }^{20}$ If we find value in a universe that is regulated by the impersonal laws of nature, it is because value is a construction of our attitudes to assess states of affairs. A state of the world or an action is judged good or bad, desirable or undesirable, better or worse, in the light of our other evaluations, which are already in place. Moral agents do not have access to a disengaged or anterior point of view. ${ }^{21}$ As the phenomenological tradition has taught us, our lived experience is always already embedded in a world loaded with meaning and value, which in turn provides the basis for evaluating states of affairs and the desirability of the possible worlds that open up before us. $^{22}$

As we will see, the acceptance of contingency and historicity does not force us to conclude that moral judgements are non-cognitive. According to Humean constructivism, normative truths flow from the substance of the practical point of view. For Street:

Normative truth consists in what is entailed from within the practical point of view. The subject matter of ethics is the subject matter of what follows from within the

20 As Rawls wrote: "[t]hus, in contrast to what Nagel calls 'the impersonal point of view,' constructivism both moral and political says that the objective point of view must always be from somewhere. This is because, as calling upon practical reason, it must express the point of view of persons, individual or corporate, suitably characterized as reasonable and rational. There is no such thing as the point of view of practical reason as such." (Rawls, Political Liberalism, p. 116).

21 As Street puts it: "Humean versions of metaethical constructivism, in contrast, deny that substantive moral conclusions are entailed from within the standpoint of normative judgement as such. Instead, these views claim, the substantive content of a given agent's reasons is a function of his or her particular, contingently given, evaluative starting points. On this view, 'pure practical reason' — in other words, the standpoint of valuing or normative judgment as such - commits one to no specific substantive values. Instead, that substance must ultimately be supplied by the particular set of values with which one finds oneself alive as an agent — such that had one come alive with an entirely different set of evaluative attitudes, or were mere causes to bring about a radical shift in those attitudes, one's reasons would have been, or would become, entirely different" (Street, "What is Constructivism in Ethics and Metaethics," p. 370).

22 Taylor, "What is Human Agency?" 
standpoint of creatures who are already taking this, that, or the other thing to be valuable. In response to the question "What is value?" constructivism answers that value is a "construction" of the attitude of valuing. What is it, in other words, for something to be valuable? It is for that thing's value to be entailed from within the point of view of a creature who is already valuing things. ${ }^{23}$

When we stop attributing disproportionate importance to thought experiments that idealize our rational capacities or the context in which we deploy them, we are left with situated agents who inherit robust moral standards and evaluations. ${ }^{24}$ Such evaluations can be seen, as Rawls suggested, as "considered judgements." 25 Both moral relativists and moral realists tend to overlook the robustness of many of our existing normative evaluations, at different levels of generality. No one individual can unilaterally make us relinquish the principle of the equal dignity of all human beings, or the judgement that child abuse is unconscionable. A person can of course refuse to see others as equals, or abuse their children, but they will thereby be violating both ethical and legal norms, and will be considered blameworthy. Unlike the laws of physics, which are indifferent to our discomforts and outcries, objective moral norms can be challenged and modified if criticism is forceful and widespread. This relative malleability should not cast doubt on the robustness of several moral norms, in particular those that have been codified in positive law. It is hard to imagine how we could abandon, from the perspective of our current moral context, the principle of the formal equality of all individuals or the judgement that slavery is a moral abomination. The idea here is not to say that it is difficult to imagine how hierarchical societies could rise from the ashes of the imperfect democratic regimes in which we now live - think, for instance, of the scenario in which a caste of individuals enhanced through gene editing and artificial intelligence take power and grant themselves similar privileges to those of the nobility in the Ancien Régime — but rather that it is difficult to imagine how the relinquishment of the fundamental right to equal dignity could come from anything other than a coup de force. I will discuss below why the contextualism inherent in Humean constructivism is not a simple democratic majoritarianism - unlike, for example, Richard Rorty's ${ }^{26}$ neo-pragmatism.

For Street, normative truths thus flow from the practical point of view of historically situated agents. However, Humean constructivism would also suffer from excessive indeterminacy if it did not go further. Up to this point, Humean constructivism holds that it is not because moral truths are contingent and contextual that they are not robust. As pointed out, it is difficult to deny the

\footnotetext{
23 Street, "What is Constructivism in Ethics and Metaethics," p. 367.

24 Hunyadi, Morale contextuelle; Moody-Adams, Fieldwork in Familiar Places.

25 Rawls, A Theory of Justice, p. 48.

26 Rorty, Contingency, Irony, and Solidarity.
} 
objectivity or normative authority of a principle such as the equal dignity of human beings, or of more specific propositions such as that child abuse is morally unacceptable. That said, in order to be a more comprehensive theory, Humean constructivism must also provide a method for responding to what Rawls called, in 1951, our "moral perplexities," namely the dilemmas and controversies about the morality of individual actions and collective decisions. ${ }^{27}$

\section{Constructivism and Coherentism}

Street rightly turns to coherentism to complement the kind of constructivism she champions, but remains vague about its specific functioning and virtues. ${ }^{28} \mathrm{~A}$ more precise exposition of the functioning of a coherentist approach, such as Rawls' reflective equilibrium, allows us to respond more satisfactorily to the concerns voiced by those who reject Humean constructivism on the grounds that it is ultimately a form of moral relativism.

Coherentism's main distinctive property is that it rejects the premise that a justified moral belief must be derived from a non-inferential belief, thus from an axiom or a first principle whose validity does not depend on its relation to other beliefs because it is true or valid in itself. Coherentism claims that truth depends on the compatibility between our judgements at all levels of generality and on the support they provide to each other. A moral judgement is thus seen as justified when it stands in a proper relation to other moral judgements in which we have confidence, and its validity depends on the solidity of the chain of logical relations in which it is embedded, as intended in the Quinian image of a web of belief. The strength of a coherentist approach is that it provides us with a somewhat structured method for proposing answers to complex moral disagreements, without having to invoke unfathomable notions, such as mindindependent moral facts, housed in a distinct order of reality, or to rely on an idealized reasoning procedure that pushes disagreement to a higher level of generality.

Let us consider the controversy surrounding the complex and delicate case of the moral acceptability of medically assisted dying. Rather than simply sticking to fairly loose inferences based on highly abstract moral principles, such as moral autonomy or the right to life, coherentism invites us to reason on the basis of all the relevant moral judgements at all levels of generality. One can point out, for instance, that the right to personal autonomy has made significant inroads in recent decades; think of the rights of patients, including children seen as 'mature minors,' with regard to medical treatment. The right of cognitively competent persons to refuse treatment, including life-saving ones, is now firmly established. The justified criticism of aggressive treatments in end-of-life care suggests that the right to life does not override other fundamental rights, or at

27 Rawls, "Outline of a Decision Procedure for Ethics," p. 188.

28 Street, "Objectivity and Truth," pp. 306-307. 
least that this right should not be interpreted as allowing health professionals to paternalistically ignore patients' preferences regarding the care they wish to receive. Finally, the fact that the practice of palliative sedation (including continuous terminal sedation) — which consists in deliberately putting terminally ill patients into a coma for specified periods of time in order to relieve their pain - is widely accepted must also be taken into consideration in a coherentist assessment of the moral acceptability of assisted dying. I won't present the whole argument here, but it seems clear that the right balance between wellconsidered moral judgements at different levels of generality - the right to moral autonomy and the critique of paternalism, the right to die by refusing lifesaving treatments, the practice of palliative sedation - strongly advocates in favour of the legalization of medical assistance in dying. In a moral context where people are considered to be agents who must discover or construct their conception of the good life (and of the good death), it seems inconsistent to refuse cognitively competent persons who suffer from serious and incurable diseases the right to assisted dying. Moreover, it seems difficult to construct a demonstration of equivalent or greater strength based on competing considered judgements, such as the slippery slope argument or the alleged irrationality of the dying person's decisions.

The purpose here is not to settle the question of the moral acceptability of assisted dying, but rather to give an example of what coherentist reasoning might look like. In short, robust moral convictions at all levels of generality serve as premises in moral reasoning and make it possible to offer justified, albeit fallible, answers to our moral perplexities. A coherentist approach such as reflective equilibrium is nothing more than a loosely formalized heuristic that allows us to clarify our moral enigmas and conflicts and, in some cases, to answer them in a transparent and reasoned way. That is why I consider that sceptics about coherentism - such as Anthony Appiah and Joseph Heath underestimate its value. ${ }^{29}$ Now, it is undoubtedly a fallible method. Mistakes can be made in attempting to weave together different considered judgements. More importantly, it is often the case that more than one judgement can reasonably be inferred from the abstract principles or specific judgements that we trust. In other words, the project of seeking reflective equilibrium, which would enable us to decisively resolve a given moral or political disagreement, cannot fully escape the previously mentioned problem of indeterminacy. For example, even if it seems clear to me that the best interpretation of the principles of equality, fairness, and freedom of conscience leads us to the conclusion that accommodation practices that allow people to respect their conscientious beliefs are sometimes morally required, there is no consensus on this position either in public opinion or in political philosophy. ${ }^{30}$ Finally, as we will see with the fictitious

29 Appiah, Experiments in Ethics, pp. 109-110; Heath, "Letting the World In."

Vallier and Weber, Religious Exemptions. 
case of an "ideally coherent Caligula," 31 it is possible to construct a logically coherent system based on false or abject moral beliefs.

In short, Humean constructivism affirms that value is produced by the human agent's disposition to consider that states of affairs and possible worlds are more or less good, just, desirable, and so on. From this point of view, moral reasoning does not depend on mind-independent moral facts, or on an abstract deliberative procedure inspired by the Kantian test of universalization, but rather on the contextual moral evaluations of agents that are historically situated. The addition of a coherentist module to Humean constructivism offers a fallible but structured approach to answer the moral conundrums and disagreements we face.

However, one of the limitations of coherentism is that it remains largely silent about the ontogenesis of morality, and more particularly about the emergence of abstract moral principles that figure predominantly in agents' most secure moral evaluations in a given context. If the moral realist tells us that the principle of the equal dignity of human beings is a universal and independent moral fact, and if the Kantian constructivist maintains that it is produced by an ideal deliberative procedure, what is the Humean constructivist's position? On this point, Street's theory is off to a good start but remains incomplete.

\section{Morality and Evolution}

Street believes that a satisfactory metaethical theory must be able to explain the relationship between morality and evolutionary theory. Like a growing number of theorists, she thinks that the pressures stemming from human biological evolution played a decisive role in the emergence of morality. ${ }^{32}$ Moral norms such as the importance of caring for children or fairness in the distribution of the burdens and benefits of collective life would have been beneficial from an evolutionary point of view by fostering the survival of offspring and cooperation between members of a group. If this is right, this entails that either some moral norms are not independent of the evaluative attitudes of humans, or that there is a striking coincidence between mind-independent moral facts and moral norms that appear to be strongly correlated to evolutionary pressures, i.e., those that have favoured the selection of members of certain groups. Given that realists have failed, according to Street, to explain why the forces of evolution have led to the emergence of moral norms that neatly correspond to independent moral facts, she argues that it is more parsimonious and scientifically plausible to think that the emergence of morality is inextricably linked to the evaluative attitudes of human beings — hence, her adherence to constructivism.

31 Street, "What is Constructivism in Ethics and Metaethics?," p. 371.

32 Greene, Moral Tribes; Joyce, The Evolution of Morality; Kitcher, The Ethical Project; Street, "A Darwinian Dilemma for Realist Theories of Value"; Waal, Macedo, and Ober, Primates and Philosophers. 
I concur with Street. The hypothesis that the first rudiments of morality have emerged to solve practical problems related to the difficulties of cooperation within groups, including the classic problems of the 'tragedy of the commons' and freeriding, is highly plausible. ${ }^{33}$ The tragedy of the commons is a situation in which, on the one hand, the members of a community are better off if they all do their part to maintain access to a shared good, and, on the other hand, each individual member has an interest in taking advantage of the benefits of cooperation without doing her share in the production or maintenance of the good in question. In this context, the emergence of moral rules and formal or informal sanctions for those who do not comply with them allows for broader and more effective social cooperation. This is why the developmental psychologist Michael Tomasello argues that morality must be seen as inextricably linked to "shared intentionality," that is, to the ability of gregarious human beings to put their minds together to formulate common intentions and commitments in cooperative activities. ${ }^{34}$ As I have pointed out, morality is thus more akin to the institutional social facts theorized by Searle than to the mind-independent facts discovered or postulated by the natural sciences. Although this is by no means a complete demonstration, it appears that the least metaphysically outlandish theory sees the first moral rules as a series of adaptive responses to the challenges of social life in a context of scarce resources and sometimes divergent interests among group members. ${ }^{35}$

That being said, thinking that selective pressures have favoured the emergence of moral rules does not entail that morality can be reduced to its ability to foster social cooperation within restricted groups. As Joshua Greene points out, the emergence of pro-social rules within communities went hand-in-hand with sharp distinctions between 'us' and 'them,' and with the adoption of standards and practices hostile towards outgroups. Although the propensity to establish a normatively meaningful distinction between us and them remains (often tragically) present today, morality gradually moved beyond its social regulation function within small groups so as to include minorities, strangers, future generations, non-human animals, and so on within the scope of moral consideration. ${ }^{36}$

33 Greene, Moral Tribes.

34 "Shared intentionality involves, most basically, the ability to create with others joint intentions and joint commitments in cooperative endeavors" (Tomasello, Why We Cooperate, p. xiii).

35 More specifically, the evolutionary theory of morality suggests that the biological evolution of Homo sapiens, subject to both random genetic variation and selective pressures, led to genetic and phenotypic mutations that fostered the gradual acquisition of various cognitive and affective capacities that have eventually enabled shared intentionality and moral reasoning.

36 Singer, The Expanding Circle. This hypothesis is consistent with Dennett's more general hypothesis that human culture was originally Darwinian and that it gradually 
Therefore, the role of evolutionary pressures in the emergence of morality does not provide us with a complete ontological theory of value. If these pressures provided the scaffold that enabled us to build human morality, to use Greene's image, the subsequent development of human cognitive faculties and of moral conscience made it possible to discard it. Morality now appears to be more independent and directed towards the justification and institutionalization of more altruistic or at least more impartial principles, whose function is to determine what we owe to others in the light of their intrinsic value.

After stating that an evolutionary perspective on morality poses a much greater challenge to realists than to constructivists, Street remains silent about the subsequent evolution of morality. What are the steps that separate the evolutionary pressures that gave birth to proto-moral rules from the practical point of view of agents at later times in human history? How, for instance, did what she refers as the "normative truth[s]" that ensue from our practical point of view emerge? This is one of the limits of Street's theory.

It should be noted at this point that coherentism does not provide the help needed. In terms of the constitution of morality, it would be too quick to assert that all justified moral beliefs are inferential. If it is easy to accept that a justified practical judgement about assisted dying is inferential, it is more difficult to argue that abstract moral principles, which play an essential role in an approach such as reflective equilibrium, are also inferential. From which judgements do principles such as human dignity, equality, fairness, freedom, or moral autonomy ensue? The normative authority of these principles does not seem at first sight to be derived from their compatibility with our considered judgements at a lower level of generality. The value of these principles seems intrinsic. One might think that these principles formalize or reduce a wide range of specific moral judgements to their common essence — think about judgements condemning slavery, religious persecution, and discrimination against LGBTQ but this would entail that specific moral judgements would be established first within moral contexts, without relying on general moral principles. Could Mary Wollstonecraft and Martin Luther King have so forcefully demonstrated that the ways in which women and African Americans were treated were profoundly unfair without using abstract ideals derived respectively from

(continued)

freed itself from this logic as human cognitive capacities evolved: "[t]he claim I defend is that human culture started out profoundly Darwinian, with uncomprehending competences yielding various valuable structures in roughly the way termites build their castles, and then gradually de-Darwinized, becoming ever more comprehending, ever more capable of top-down organization .... In short, as human culture evolved, it fed on the fruits of its own evolution, increasing its design powers by utilizing information in ever more powerful ways" (Dennett, From Bacteria to Bach and Back, p. 148). 
Enlightenment philosophy and from the American social imaginary? It is certainly not uncommon that we revise our interpretation of abstract moral concepts according to the evolution of the social context - for example, when we conclude that the right to equality requires differential treatment for certain categories of persons ('reasonable accommodation') or that the right to autonomy calls for the legalization of assisted dying — but that does not entail that abstract principles are nothing but a posteriori formalizations.

In addition, moral coherentism posits that the validity of individual moral judgements depends on the mutual support conferred by the entire set of beliefs that constitute a given system. Yet, if we accept the thesis that the space of moral reasons is plural, that is to say constituted by distinct and irreducible moral principles, we must accept that there may be conflicts between our moral evaluations at different levels of generality. For example, tension can arise between the standard conception of fairness - 'to each her own' - and a duty of solidarity towards people in need who could be at least partly responsible for their own fates. The ideal that people should be able to choose their own conception of what a meaningful life is allows some to adhere to beliefs that are incompatible with the principle of the moral equality of persons. The method of reflective equilibrium cannot lead to the elimination of all conflicts within our moral context. Rather, its purpose is to allow us to identify the answers to our moral perplexities that are most coherent in the light of a subset of our properly supported judgements with minimal infringement upon the other moral principles and judgements we hold dear as well.

In short, coherentism tells us little about the emergence of abstract moral principles, which are the agent's most basic moral evaluations in a given context. Street's constructivism accepts the thesis according to which evolutionary pressures are at the root of some proto-moral practices, such as the sacrifices that parents make to ensure the survival and maturation of their offspring, or the establishment of rules that promote fair cooperation within groups. For his part, Rawls adopts a "method of avoidance" - that is to say an agnostic position with regard to what he classifies as metaphysical issues. ${ }^{37}$ Instead, he falls back on a form of moral contextualism, according to which he extracts normative conceptions of the person and of society from the background political culture of liberal democracies. ${ }^{38}$ In the last part of this paper, I will assume that the Rawlsian metaphysical restraint is justified only in the context of a theory of

37 Rawls, Political Liberalism, p. 29.

"We start, then, by looking to the public culture itself as the shared fun of implicitly recognized basic ideas and principles. We hope to formulate these ideas and principles clearly enough to be combined into a political conception of justice congenial to our most firmly held convictions" (Rawls, Political Liberalism, p. 8.) 
public reason and will argue that Humean constructivism must be further historicized. ${ }^{39}$ The aim is to arrive at a coherent and plausible ontological position about the emergence of moral norms and the constitution of a practical point of view.

\section{Historical Intersubjectivity in Humean Constructivism}

As we have seen, if Street urges us to accept that there is contingency at the very foundation of morality, her characterization of the point of view from which morality is constructed remains voluntarily formal and rather schematic. There is a gap between, on the one hand, her reflection on the relationship between evolutionary theory and morality and, on the other hand, her formal characterization of the practical point of view. I want to suggest that this gap can be filled with what may be called, for lack of a more prosaic notion, 'historical intersubjectivity.' Historical intersubjectivity is made up of the different forms of collective intentionality, as theorized by Searle and Tomasello, which refer to the capacity of human beings to collectively formulate intentions and to make commitments in order to pursue their common interests. ${ }^{40}$ From a deflationary Hegelian perspective, the objectivity of reasons for action is seen as being derived from historical intersubjectivity and established social practices. ${ }^{41}$ As Manne summarized, this tradition of thought considers that at least a subset of our reasons for action stems from the social practices in which we participate

39 Rawls sometimes suggests that political liberalism's neutrality with respect to comprehensive doctrines requires this metaethical agnosticism. It seems to me that he confuses the legislator's point of view with that of the philosopher's. What matters is that the reasons supporting public norms and institutions are secular or public, i.e., acceptable in principle from the point of view of all reasonable comprehensive doctrines. This relative neutrality of justifications is compatible with philosophers' engagement with metaphysical issues. In other words, it is possible both to be a defender of political liberalism in political philosophy and to adhere to a particular thesis in moral ontology (Maclure, "La philosophie politique analytique et ses critiques").

40 'Collective intentionality' refers here to a collective agent's capacity to formulate a common intention, i.e., a plan to act in a specific way, rather than to the more basic mental activity according to which the mind aims at an object of reference.

41 " $[\mathrm{I}] \mathrm{n}$ world history the outcome of human actions is something other than what the agents aim at and actually achieve, something other than what they immediately know and will. They fulfill their own interests, but something further is thereby brought into being, something which is inwardly involved in what they do but which was not in their consciousness or part of their intention" (Hegel, Introduction to the Philosophy of History, p. 30). 
rather than from independent objective facts or from an agent's individual desires. $^{42}$ This is the position that Manne calls "intersubjectivism"

Such a view may be understood as a form of intersubjectivism - one which identifies the social practice, specifically, as generating the practical reasons in question. So, a proponent of (what I'll thus call) a practice-based view about a certain type of reason will claim that these reasons arise directly from facts about what we do, or about what one does, as a participant in certain sorts of collective practices, joint enterprises, or particular social relationships. These practices ... are not supposed to be objectively given to us, but not are they supposed to be a matter of individual decision-making or choice. Rather, they will generally be the historical products of a process of collective negotiation and collaboration that is entirely man-made, but not by any one man or woman. $^{44}$

The more specific hypothesis I want to sketch is that, once the initial momentum has been given by evolutionary pressures, the continuous development of morality is intimately linked to historical intersubjectivity, which is not only constituted by practical deliberation, but also by a specific genre of social practices, that is the multitude of human struggles carried out in the name of justice and recognition. ${ }^{45}$ What Humean constructivism and intersubjectivism must factor in is that the expression of disagreement, the resistance to perceived injustices, and the claiming of rights are generally necessary for new principles and moral judgements to settle in a given social context and recompose the common moral sense.

Consider the example of the status of Aboriginal peoples in Canada, and, in particular, the issue of residential schools. ${ }^{46}$ Few today think that forcing Indigenous children out of their communities to attend Catholic or Protestant residential schools without being allowed to see their family members during the school year or to speak their native languages was a morally acceptable policy. Something has changed in the web of our moral evaluations since the 1960s. How can this transformation be explained? It is probably not possible to demonstrate that realist and procedural rationalist theories cannot explain this

42 Manne, "On Being Social in Metaethics"; see also Laden, Reasoning.

43 Manne, "On Being Social in Metaethics," p. 51. However, this is a different type of intersubjectivism from that defended by Kantian constructivists. Contextualists see historically situated social practices as the relevant sources of normativity, whereas Kantian constructivists rely on idealized (intersubjective) deliberative procedures.

44 Manne, "On Being Social in Metaethics," pp. 51-52.

45 Honneth, The Struggle for Recognition. The Moral Grammar of Social Conflicts; Taylor, "The Politics of Recognition."

46 See the final report of the Truth and Reconciliation Commission of Canada: http:// www.trc.ca/about-us/trc-findings.html. 
change, but a materialist ${ }^{47}$ conception of the social world certainly reveals that this process of revising our moral evaluations was preceded by the struggles for recognition and the practices of resistance deployed by Indigenous peoples. ${ }^{48}$ It is not because Canadians have spontaneously seen the moral light, or have deployed an abstract deliberative procedure, that we have (slowly and modestly) made progress in recognizing the rights of Indigenous peoples. It is still possible for moral realists and Kantian constructivists to affirm that the Lockean or other justifications of the political subordination of Indigenous peoples in North America were at odds with an independent moral reality, or that they emanated from an incorrect deliberative procedure, but it is more parsimonious to fall back on what sociology and history teach us: the material practices of opposition and resistance are necessary for the transformation of moral contexts and for the sedimentation of new normative principles and judgements. These struggles cannot do without ideas and arguments, but ideas and arguments are often thought of, developed, and revised in the context of social practices and, particularly, of political struggles. ${ }^{49}$ If it was in the natural order of things for the Ancient Greeks to see foreigners as barbarians who could be treated as slaves after a military victory, ${ }^{50}$ and to see women as insufficiently rational so as to participate in the affairs of the city ${ }^{51}$ we can reasonably think that resistance and the vindication of rights have proved to be instrumental to these moral transformations.

A further reason to think that the expression of disagreement, opposition, and resistance are necessary, in addition to rational reflection and deliberation, to moral change, is that any Humean rather than Kantian perspective must take into consideration the limits of human rationality as actually deployed by agents, as opposed to idealized by philosophers. It is now well established that the typical epistemic agent has cognitive biases that lead him to rationalize the unfair benefits he enjoys and to defend the status quo when it serves his interests. ${ }^{52}$ As Michele Moody-Adams writes in response to a thesis by the moral realist Nicholas Sturgeon on the injustice of slavery, the "culpable capacity" to ignore the suffering of others has been essential to the persistence of slavery: "[ $t]$ he persistence of slavery in the New World, I contend, should be attributed not to a presumed failure to perceive a moral property of 'wrongness,' but to a widespread and morally culpable capacity to ignore willingly the suffering of

47 I mean 'materialist' here not as a synonym for 'naturalist,' but rather as referring to currents of thought that emphasize the role of praxis in shaping social imaginaries. Alfred, Heeding the Voices of Our Ancestors; Tully, "The Struggles for Indigenous Peoples for and of Freedom."

49 Taylor, Modern Social Imaginaries.

50 Plato, The Republic, Book 4.

51 Aristotle, Politics, Book 1, Chapter 5.

52 Kahneman, Thinking, Fast and Slow; Stanovich, Rationality and the Reflective Mind. 
human beings. $" 53$ It is thus reasonable to think that opposition and contestation are generally necessary to transform our moral evaluations. If this is true, it suggests that moral reality, or the order of moral reasons, is not independent of human evaluative attitudes and in particular of their conception of justice, their deliberations, and their ability to oppose perceived injustices.

\section{The Space of Moral Reasons}

Before I conclude, I would like to briefly explain why historicized constructivism is compatible with one of the most attractive non-naturalist realist theses, namely the view that we are always moving within a space of (normative) reasons that precedes us and whose normative authority we must be responsive to. ${ }^{54}$ For instance, Charles Larmore writes that "there is a normative order to which thought is called upon to respond, an objective order of reasons of which we are not ourselves the authors, but whose authority we should recognize (and that we don't institute)." 55

It is true that there is space of moral reasons that precedes us and that has a certain independence in the sense that we cannot change it at will. As we saw, widely accepted premises in moral reasoning - propositions such as, for example, 'human beings deserve equal respect and should be treated equally by public authorities, regardless of their ethnic or gender identities' - often have robust objectivity, and the rules of logical reasoning often force us to accept inferences that become well-considered moral judgements - e.g., 'slavery is profoundly unjust.' It is true that such moral conclusions are probably better seen as discovered or figured out by the mind, rather than as constructions.

However, this does not warrant the view that the space of moral reasons is completely independent of our attitudes and practices in the same way as external physical reality is, and that it is by no means the result of collective intentionality, deliberation, and concrete social practices. Rather, experience suggests that the order of moral reasons is to some extent malleable, and always evolving because it is correlated with human attitudes — but much more slowly and modestly than what radical constructivists claim, including the non-cognitivist theorists inspired by genealogical or deconstructivist approaches in continental philosophy. There is nothing in the theory of the space of moral reasons that shows that moral truths are nested in a distinct realm of reality, or that they can be derived from natural properties alone or simply intuited. ${ }^{56}$ It only

53 Moody-Adams, Fieldwork in Familiar Places, p. 98.

54 This is an adaptation of Wilfrid Sellars' concept of the 'space of reason' to the context of morality. For two versions of this thesis, see Larmore, The Autonomy of Morality and Scanlon, Being Realistic about Reasons.

55 Larmore, "Une éthique des raisons," p. 46.

56 See, for instance, Brandom's normative and inferentialist theory of rationality: “ $[\mathrm{t}] \mathrm{his}$ is the idea that normative statuses are attitude-dependent. It is the idea that authority, 
suggests that, once in place in a given social imaginary, the space of moral reasons is largely discovered rather than constructed. Contextualist constructivism is perfectly capable of accommodating this conclusion, ${ }^{57}$ even though it entails that we break with Street's methodological individualism and develop the notion of a heterogeneous collective practical point of view, which contains the normative resources to criticize the social norms that are considered by some to be unjust. Realists, on their side, must ask themselves why the authority of certain moral reasons - such as recognizing that the equal moral worth of Aboriginal peoples is a reason for jettisoning assimilative policies — is not recognized at a particular point in time and why it becomes so thereafter.

As I have just alluded to, I suspect that Street's methodological individualism contributes to the view that Humean constructivism can hardly account for the objectivity of morality (or, at least, for the robustness of many moral principles and judgements). ${ }^{58}$ Street is not wrong to think that agents have an individual practical point of view whose substance is given by their set of moral evaluations. However, this does not justify neglecting the collective and institutional aspects of morality. An "ideally coherent Caligula" but highly improbable, because agents are always situated within a moral context that transcends them and that shapes the point of view from which they can make moral claims. As pointed out earlier, agents may of course not comply

(continued)

responsibility, and commitment were not features of the non- or pre-human world. They did not exist until human beings started taking or treating each other as authoritative, responsible, committed, and so on - that is, until they started adopting attitudes toward one another .... This view of the global attitude-dependence of norms contrasts with the traditional objectivist one, according to which the norms that determine what is 'fitting' in the way of human conduct are to be read off features of the non-human world that are independent of the attitudes of those subject to the norms" (Brandom, Reason in Philosophy, p. 61).

57 Hunyadi, Morale contextuelle; Moody-Adams, Fieldwork in Familiar Places.

58 I see Street as adhering to methodological individualism because her concept of the practical point of view is voluntarily individualistic. As a result, she appears to overlook the intersubjective nature of morality: "It's important to emphasize that on a constructivist account, there is still normative truth and objectivity. It's just that the level of objectivity isn't quite as robust as the realist thought. While it's entirely possible to make normative errors on a constructivist view, and we do so all the time, the standards of correctness that determine what are and aren't errors are ultimately set by the normative judgments of the person whose reasons are in question" (Street, “Objectivity and Truth," p. 332, my emphasis).

59 That is, an agent with psychopathic tendencies for whom torturing others is a source of pleasure and whose belief system and attitudes are perfectly coherent (Street, "What is Constructivism in Ethics and Metaethics?," p. 371). 
with these rules, but this does not alter their authority, and agents must generally assume the consequences of their non-compliance. ${ }^{60}$ These rules become pro tanto reasons to act in accordance with them. A third factor, such as mental illness or personality disorders, is necessary to explain how a person can become an ideally coherent Caligula. It is true that contextualist constructivism does not offer any resources to criticize a morally homogeneous society exclusively made of "coherent Caligulas," but the societies that concern us in our actual world are morally heterogeneous - that is, societies in which it is generally possible to find the moral resources to criticize unfair institutions. This is why I think that intersubjectivism is a welcome corrective to Street's individualistic conception of the practical point of view.

\section{Conclusion: Morality as a Collective Achievement}

I argued in this paper that Humean constructivism is the most parsimonious and promising theory in moral ontology. But Humean constructivism must clarify the role of coherentism and further develop its contextualist nature. I suggested that, after recognizing the role of evolutionary pressures on the development of proto-moral practices, it must explicitly recognize the contribution of historical intersubjectivity and, more specifically, of social practice such the practices of resistance of agents who oppose the norms that they consider unfair within their moral context. From this point of view, morality does not constitute an independent order of reality and is not produced by an ideal deliberative procedure. Rather, it must be seen as a permanent intersubjective construction and, above all, an ever-precarious collective achievement. The further development of the thesis proposed here will, among other things, require a reflection on the status of the notion of moral progress. ${ }^{61}$ Nothing in what I have said constitutes a proper refutation of moral realism or of Kantian constructivism. I tried to make the case that contextualist constructivism retains what we are looking for in a metaethical theory without postulating the existence mind-independent moral facts or conferring unrealistic powers to practical reasoning.

60 Street acknowledges this in a laconic passage from her critique of Dworkin's thesis, but she does not explain how the relationship between the individual practical point of view and what I have called the 'collective practical point of view' should be thought of: "[s]ome conceivable agents have reason to exterminate an ethnic group or enslave a race or torture a young child for fun in front of its captive mother, but most real life human beings have no such reasons, and if we ever encounter any who do, then we (you and I and the vast majority of human beings) have reason to band together against them, lock them up, and throw away the key" (Street, “Objectivity and Truth," p. 326).

61 Moody-Adams, "Moral Progress and Human Agency," and Pinkard, Does History Make Sense? Hegel on the Historical Shapes of Justice are useful starting points for this reflection. 


\section{Acknowledgements}

I wish to thank Didier Zuniga for the translation of this paper from French, as well as Éric Gagnon for his research assistance.

\section{References}

Alfred, Gerald R.

1995 Heeding the Voices of Our Ancestors. Toronto/New York: Oxford University Press.

Appiah, Kwame Anthony

2008 Experiments in Ethics. Cambridge: Cambridge University Press.

Aristotle

2009 The Politics. Trans. by E. Barker. Oxford: Oxford's Paperbacks.

Aubé Beaudoin, Félix

2014 Faits moraux et évolution : un dilemme pour le réalisme moral, mémoire de maîtrise, Université Laval, disponible en ligne : http://theses. ulaval.ca/archimede/meta/30741.

Bagnoli, Carla

2017 "Constructivism in Metaethics," in The Stanford Encyclopedia of Philosophy [online], edited by Edward N. Zalta. https://plato.stanford. edu/archives/fall2017/entries/constructivism-metaethics/ (Fall 2017).

Brandom, Robert

2009 Reason in Philosophy. Cambridge: Belknap Press of Harvard University Press.

Darwall, Stephen, Allan Gibbard, and Peter Railton

1992 "Toward Fin de siècle Ethics: Some Trends." The Philosophical Review 101(1): 115-189.

Dennett, Daniel C.

2017 From Bacteria to Bach and Back: The Evolution of Minds. New York: W.W. Norton \& Company.

Desmons, Ophélie

2013 Les présupposés du libéralisme politique : quelle justification? John Rawls et l'hypothèse herméneutique, thèse de doctorat, Université de Lille 3 en cotutelle avec l'Université Laval, disponible en ligne : http://www.theses.fr/2013LIL30021.

Dworkin, Ronald

1996 “Objectivity and Truth: You'd Better Believe It.” Philosophy \& Public Affairs 25(2): 87-139.

Enoch, David

2009 "Can There Be a Global, Interesting, Coherent Constructivism about Practical Reason?” Philosophical Explorations 12(3): 319-339.

Gabriel, Markus

2015 Fields of Sense: A New Realist Ontology. Edinburg: Edinburg University Press. 
Greene, Joshua

2013 Moral Tribes: Emotion, Reason, and the Gap Between Us and Them. New York: Penguin Press.

Habermas, Jürgen

1984 The Theory of Communicative Action. Vol. I: Reason and the Rationalization of Society. Trans. by T. McCarthy. Boston: Beacon.

Habermas, Jürgen

1990 Moral Consciousness and Communicative Action. Trans. by C. Lenhardt and S. Weber Nicholsen. Cambridge: The MIT Press.

Heath, Joseph

2012 "Letting the World In: Empirical Approaches to Ethics." Les ateliers de l'éthique 7(3): 93-107.

Hegel, G.W.F.

1988 Introduction to the Philosophy of History. Trans. by L. Rauch. Indianapolis: Hackett.

Honneth, Axel

1996 The Struggle for Recognition: The Moral Grammar of Social Conflicts. Cambridge: Polity Press.

Hunyadi, Mark

2008 Morale contextuelle. Québec: Presses de l'Université Laval. Jacobs, Jonathan A.

2008 Dimensions of Moral Theory. An Introduction to Metaethics and Moral Psychology. New York: Wiley.

Joyce, Richard

2006 The Evolution of Morality. Cambridge: The MIT Press.

Kahneman, Daniel

2011 Thinking, Fast and Slow. London: Allen Lane.

Kant, Immanuel

1992 Fondements de la métaphysique des mœurs [1785]. Trans. by V. Delbos. Paris: Vrin.

Kitcher, Philip

2011 The Ethical Project. Cambridge/London: Harvard University Press. Laden, Anthony Simon

2012 Reasoning: A Social Picture. Oxford: Oxford University Press.

Larmore, Charles

2004 "Une éthique des raisons," in Débat sur l'éthique, edited by A. Renaut and C. Larmore. Paris: Grasset, pp. 45-90.

Larmore, Charles

2008 The Autonomy of Morality. Cambridge: Cambridge University Press. Maclure, Jocelyn

2006 "On the Public Use of Practical Reason: Loosening the Grip of Neo-Kantianism," Philosophy \& Social Criticism 32(1): 37-63. 
Maclure, Jocelyn

2012 "La philosophie politique analytique et ses critiques," in Ceci n'est pas une idée politique. Réflexions sur les approches à l'étude des idées politiques, edited by D. Giroux and D. Karmis. Québec: Presses de l’Université Laval, pp. 261-288.

Manne, Kate

2013 "On Being Social in Metaethics," in Oxford Studies in Metaethics, vol. 8, edited by R. Shafer-Landau. Oxford: Oxford University Press, pp. $50-73$.

Miller, Alex

2003 An Introduction to Contemporary Metaethics. Cambridge: Polity Press. Moody-Adams, Michele M.

2002 Fieldwork in Familiar Places: Morality, Culture, and Philosophy. Cambridge: Harvard University Press.

Moody-Adams, Michele M.

2016 "Moral Progress and Human Agency." Ethical Theory \& Moral Practice 20(1): 153-168.

Ogien, Ruwen

1999 “Qu'est-ce que le réalisme moral?" in Le réalisme moral. Paris: Presses Universitaires de France, pp. 3-194.

O’Neill, Onora

1989 Constructions of Reason. Cambridge: Cambridge University Press.

Pinkard, Terry

2017 Does History Make Sense? Hegel on the Historical Shapes of Justice. Cambridge: Harvard University Press.

Plato

2000 The Republic. Trans. by B. Jowett. Mineola: Dover Publications.

Rawls, John

1951 “Outline of a Decision Procedure for Ethics.” The Philosophical Review 60(2): 177-197.

Rawls, John

1971 A Theory of Justice. Cambridge: Belknap Press of Harvard University Press.

Rawls, John

1980 "Kantian Constructivism in Moral Theory." The Journal of Philosophy 77(9): 515-572.

Rawls, John

1993 Political Liberalism. Cambridge: Belknap Press of Harvard University Press.

Rorty, Richard

1989 Contingency, Irony, and Solidarity. Cambridge/New York: Cambridge University Press. 
Scanlon, Thomas M.

1982 "Contractualism and Utilitarianism," in Utilitarianism and Beyond, edited by A.K. Sen and B.A.O. Williams. Cambridge: Cambridge University Press, pp. 103-128.

Scanlon, Thomas M.

2000 What We Owe to Each Other. Cambridge: Belknap Press of Harvard University Press.

Scanlon, Thomas M.

2014 Being Realistic about Reasons. Oxford: Oxford University Press.

Searle, John

2011 Making the Social World: The Structure of Human Civilization. New York: Oxford University Press.

Singer, Peter

2011 The Expanding Circle: Ethics and Sociobiology. Princeton: Princeton University Press.

Stanovich, Keith

2011 Rationality and the Reflective Mind. Oxford/New York: Oxford University Press.

Street, Sharon

2006 “A Darwinian Dilemma for Realist Theories of Value.” Philosophical Studies 12(1): 109-166.

Street, Sharon

2010 "What is Constructivism in Ethics and Metaethics?" Philosophy Compass 5(5): 363-384.

Street, Sharon

2016 "Objectivity and Truth: You'd Better Rethink It," in Oxford Studies in Metaethics, vol. 11, edited by R. Shafer-Landau. Oxford: Oxford University Press, pp. 293-333.

Taylor, Charles

1977 "What is Human Agency?," in The Self: Psychological and Philosophical Issues, edited by T. Mischel. Oxford: Blackwell, pp. 103-135.

Taylor, Charles

1994 "The Politics of Recognition," in Multiculturalism: Examining the Politics of Recognition, edited by A. Gutmann. Princeton: Princeton University Press, pp. 25-73.

Taylor, Charles

2004 Modern Social Imaginaries. Durham: Duke University Press.

Tomasello, Michael

2009 Why We Cooperate. Cambridge: The MIT Press.

Tully, James

2008 "The Struggles for Indigenous Peoples for and of Freedom," in his Public Philosophy in a New Key, vol. 1. Cambridge: Cambridge University Press, pp. 257-288. 
Turmel, Patrick, and David Rocheleau-Houle

2016 "Le constructivisme est-il une métaéthique?" Revue de métaphysique et de morale 91(3): 353-376.

Vallier, Kevin, and Michael Weber

2018 Religious Exemptions. Oxford: Oxford University Press.

Waal, Frans de, Stephen Macedo, and Josiah Ober

2006 Primates and Philosophers: How Morality Evolved. Princeton: Princeton University Press. 